\title{
MUCH ADO ABOUT FOOD SAFETY REGULATION IN NIGERIA
}

\author{
Jane Ezirigwe*
}

\begin{abstract}
About 1 in 10 people in the world fall sick after eating food contaminated through improper farming, processing, preservation and services. In Nigeria, more than 200,000 persons die of food poison annually, caused by contaminated foods. The cost of illnesses associated with foodborne diseases in Nigeria is estimated at US\$ 3.6 billion per annum. Though there is poor data collection on foodborne outbreaks, evidence exists to show that these contribute to ill health and death in the country as well as reduce productivity and economic growth. Studies and existing facts reveal that law makers, enforcement officers, regulators, food handlers and even the consuming public do not take food safety very seriously. This article examines the varied cases of foodborne outbreaks in Nigeria with the aim to assess the role and ambit of food safety regulations in Nigeria. It seeks to determine whether the present regulatory framework permits adequate regulation of the informal sector that serves the majority of the Nigerian consumers. While observing various challenges that may be encountered by the regulators, it offers recommendations on issues that require legislative reforms and pragmatic approaches in tackling the regulatory challenges. It concludes that the intergovernmental and the multi-agency cooperation envisaged by the National Policy on Food Safety and its Implementation Strategy, 2014, will be better achieved if the definition of "food" in the food laws are extended, in line with best practices and current realities, to allow for comprehensive regulation and coordination of the food chain system.
\end{abstract}

Keywords: Food Safety, Foodborne Illnesses, Food Regulation, Food Security.

DOI: https://dx.doi.org/10.4314/jsdlp.v9i1.6

* LLB (Hons.) Abuja, LLM (London), MBA (EBS), Research Fellow, Nigerian Institute of Advanced Legal Studies. Doctoral Scholar, University of Cape Town, South Africa. email: ezirigwejane@gmail.com 
"If it is not safe, it is not food" - Markus Lipp, FAO.

\section{INTRODUCTION}

An estimated 600 million - about 1 in 10 people in the world - fall sick after eating contaminated food, ${ }^{1}$ and as a result of this, 420,000 die every year, resulting in the loss of 33 million healthy life years (DALYs). ${ }^{2}$ In Nigeria, more than 200,000 persons die of food poison annually, caused by food contaminated through improper farming, processing, preservation and services. ${ }^{3}$ Improper farming techniques and food processing methods, products adulteration as well as contamination picked up during processing are possible sources for food-borne diseases. The amount of chemicals used for preservation, medium of sale and tampering with expiry dates are also possible sources. In addition, the methods of cooking, and the sanitary conditions of the cooking environment, ${ }^{4}$ as well as the personal hygiene of food handlers are all possible sources of food-borne diseases in Nigeria. ${ }^{5}$

Our changing lifestyles have encouraged food outlets and food vendors, ${ }^{6}$ with a large proportion of ready-to-eat foods sold by the informal sector, especially as street food. ${ }^{7}$ Many of the food vendors are itinerant in nature. Some push their food-laden carts, wheel-barrows

1 "Food Safety- Fact Sheet" (Reviewed October, 2017) <www.who.int/ mediacentre/factsheets/fs399/en/> accessed 12 October 2017. This means that annually, 1 out of 10 people in the world suffer from foodborne disease.

2 ibid.

3 Premium Times , "200,000 people die of food poison annually in Nigeria- Prof. Ihenkuronye" -Premium Times <www.premiumtimesng.com/news/96700200000-people-die-of-food-poison-annually-in-nigeria-prof-ihenkuronye.html> accessed 11 October 2017; Nne Pepple, "Environment and Food Poisoning: Food Safety Knowledge and Practice among Food Vendors in Garki, Abuja Nigeria" (2017) 5 J Health Educ Res Dev. 217.

4 Sylvester N. Onyeneho and Craig W. Hedberg, "An Assessment of Food Safety Needs of Restaurants in Owerri, Imo State, Nigeria" (2013) 10 International Journal of Environmental Research and Public Health 3296.

5 See studies by Pepple (n 3); Onyeneho and Hedberg (n 4).

6 Federal Ministry of Health, Abuja, "National Policy on Food Safety and its Implementation Strategy, 2014",10 <www.health.gov.ng/doc/FoodSafety Policy.pdf $>$ accessed 2 February 2018.

7 Isaac Adewole, "Food Safety as an Important Global Public Health and Economic Concern", Health News NG.com, 8 February 2017. < http://healthnewsng.com/ food-safety-important-global-public-health-economic-concern/ $>$ accessed 10 February 2018. 
or specially-designed bicycles from one location to another to serve their customers. ${ }^{8}$ Others operate as bukas in small stalls and batchers. These street foods are sold at relatively low prices, thus attracting the majority of low-income workers, shoppers, travellers and school children - the majority of the Nigerian population. These people are often more interested in money saving and time convenience than issues of safety, quality and hygiene. ${ }^{9}$

Unfortunately, there is poor data collection on food-borne outbreaks in Nigeria. The absence of appropriate surveillance systems makes it difficult to have an accurate representation of the burden of food-borne disease. However, evidence shows that these food-borne outbreaks contribute to ill health and death in the country. ${ }^{10}$ There is also evidence of unsafe food practices by food producers, manufacturers, processors, caterers and handlers in the food chain system. ${ }^{11}$ Studies and existing facts reveal that the lawmakers, law enforcement officers, regulators, food handlers and the consuming public do not take food safety very seriously. ${ }^{12}$

With the looming global food crisis and the rapidly growing Nigerian population, ${ }^{13}$ the subject of food security should occupy the centre stage of discourse. Food safety is a very significant element of food security. Food safety is the "assurance that food will not cause harm to the consumer when it is prepared and/or eaten according to its intended use."14 The establishment of an effective food control and regulation system is the key component of ensuring food safety. There is need to safeguard the quality and safety of food both for domestic consumption and for exportation.

This article examines the varied cases of foodborne outbreaks in Nigeria with an aim to assess the ambit and efficacy of food safety

\footnotetext{
Onyeneho and Hedberg (n 4) 3297.

Adewole (n 7)

10 See section 2.1 below.

11 See section 2.1 below.

12 See section 2.1 below.

13 Nigeria is projected to be the third most populous nation by 2050. See United Nations, Department of Economic and Social Affairs, Population Division, World Population Prospects: The 2017 Revision, Key Findings and Advance Tables (Working Paper No. ESA/P/WP/248, 2017) 5.

14 World Health Organization, and Food and Agriculture Organization of the United Nations. Codex Alimentarius Commission, Food Hygiene, (4th Edition, FAO and WHO 2009) 6 <http://www.fao.org/docrep/012/a1552e/a1552e00.pdf > accessed 10 February 2018.
} 
regulation in the country. It aims to determine whether the present regulatory framework permits adequate regulation of the informal sector that serves the majority of the Nigerian consumers. Section 2 discusses the need for an effective food safety regime in Nigeria by recounting some of the foodborne outbreaks and analysing some of the effects of an ineffective food safety regime on the populace and the economy. Section 3 evaluates the current regulatory structure on food safety in Nigeria. It enumerates the legal framework, assesses the enforcement regimes and observes concerns for reforms. Section 4 examines issues requiring reforms while section 5 offers proposals on how to address practical and on-the-ground challenges to reform that may be encountered by the regulators. Section 6 is the conclusion.

\section{THE NEED FOR EFFECTIVE FOOD SAFETY REGIMES IN NIGERIA}

Effective food safety regimes will entail the existence of comprehensive laws, coupled with an effective food control infrastructure and institutional capacities, to ensure compliance in providing consumer protection. Laws should adequately address the whole range of food safety concerns. Adequate infrastructure in terms of coordination, surveillance system and budgetary provisions ought to be appropriately convoked. Institutional capacities should be certified, with provisions for training and capacity building. This section seeks to emphasize the importance of effective food safety regimes by, first, recounting the several cases of food borne outbreaks in Nigeria. It goes on to bare different studies that show ignorance, negligence and neglect by the food handlers as well as inadequate regulation by the regulators. It concludes by analysing possible effects of the menace on the Nigerian populace and the economy.

\subsection{Situation Analysis}

Foodborne diseases or illnesses result from ingestion of foodstuffs or drinks contaminated with microorganisms or chemicals. ${ }^{15}$ Global incidence of foodborne diseases is rather alarming. ${ }^{16}$ The Center for Disease

15 WHO, "Foodborne diseases" World Health Day, 7 April $2015<$ http:// www.who.int/topics/foodborne_diseases/en/> accessed 10 February 2018.

16 Godwin E. Ifenkwe, "Food Safety Regulations: Reducing the Risk of Foodborne Diseases in Rural Communities of Abia State, Nigeria" (2012) 2 Agricultural Science Research Journals 384, 385. 
Control and Prevention (CDCP) estimates an annual occurrence of 47.8 million and 2 million food-borne illnesses in the United States and United Kingdom, respectively. ${ }^{17}$ It also reckons that in Australia, there are 5.4 million cases of foodborne illnesses annually, triggering 18,000 hospitalizations, 120 deaths, 21 million lost work days, 1.2 million doctor consultations and 300,000 prescriptions for antibiotics. ${ }^{18}$ It is improbable that Nigeria's food borne episodes have fared better than these figures, given that these are developed countries with higher standards of living, good water supplies, improved toilet management systems, wellstructured surveillance systems and more proactive governments.

Experts have argued, and rightly so, that underreporting and underestimation of incidence of foodborne diseases in developing countries will affect the kind of measures and strategies implemented to curb foodborne disease outbreaks. ${ }^{19}$ The culture of self-prescription precludes cases from getting to the hospitals and being treated by physicians. Most symptoms of foodborne illnesses such as vomiting, diarrhoea and fever are considered common ailments and are often handled by purchase of self-prescribed medication. ${ }^{20}$

Notwithstanding the paucity of data on foodborne outbreaks in Nigeria, there have been documented cases of foodborne illness outbreaks. In Ibadan, Oyo State, an outbreak attributed to the consumption of improperly preserved sandwiches contaminated with the Salmonella virus resulted in the death of 20 people. ${ }^{21}$ A study revealed that staphylococcal aureus infection was the leading cause of another food poison incident that happened in Ambrose Alli University and its environs. ${ }^{22}$ There was also an acute onset of gastrointestinal symptoms among people who had attended and eaten at a burial ceremony resulting to three deaths and 60 case patients. ${ }^{23}$

17 Ibid.

18 Ibid.

19 Olumide A. Odeyemi, "Public Health Implications of Microbial Food Safety and Foodborne Diseases in Developing Countries" (2016) 60 Food \& Nutrition Research 1.

20 Onyeneho and Hedberg (n 4) 3298.

21 Kayode Osagbemi, Ayoade Ahmad. Abdullahi, and Sunday Aderibigbe, "Knowledge, Attitude and Practice Concerning Food Poisoning among Residents of Okene Metropolis, Nigeria" (2010) 1 Res. J. Soc. Sci. 61, 61-64.

22 V Oni, Osaretin Oni and Fred Esumeh, "Prevalence of Bacteria Food Poison from Vegetable Salads" (2009) 10 The Internet Journal of Nutrition and Wellness 2.

23 Akinola A Fatiregun, Olowogboyega. Oyebade and L Oladokun, "Investigation of an Outbreak of Food Poisoning in a Resource-Limited Setting" (2010) 17 Trop. J. Health Sci. 1117. 
In 2017, in a settlement predominantly inhabited by Fulani herdsmen, gastroenteritis, a diarrheic ailment triggered by zoonotic bacteria, was identified as the cause of 62 deaths in Yagba West, Kogi state. ${ }^{24}$ In 2015 , there was a report of food poisoning caused by toxic metals in Zamfara State which resulted in the death of numerous infants and children. ${ }^{25}$ In Kano State, there was a case of food poisoning among three families due to yam flour consumption. Investigations revealed that the use of certain lethal preservatives for the processing of the yam flour might be responsible. ${ }^{26}$ Another food poisoning report attributed to yam flour consumption in five families in Ilorin, Kwara State of Nigeria was also reported. ${ }^{27}$

The rising cases of food poisoning in Nigeria have also been linked to the misuse and abuse of agrichemicals on agricultural products. Nigeria is one of the countries with the largest projected increases in antibiotics consumption for veterinary services. ${ }^{28}$ Studies have revealed antibiotic residues from penicillins, tetracyclines, streptomycin and erythromycin in meat from livestock and poultry, some having values higher than the World Health Organisation (WHO) recommended tolerance levels, ${ }^{29}$ with heavy concentrations found in the internal organs. ${ }^{30}$ Pesticides are an important part of food production. They are used to shield crops and livestock from various pests and diseases and

24 Olatunji Ololade, "Dangerous Meat, Toxic Waters 3: Nigerians Die From 'Food Poisoning"' The Nation (26 August 2017) < http://thenationonlineng.net/ dangerous-meat-toxic-waters-3-nigerians-die-food-poisoning/> accessed 15 October 2017.

25 Pepple (n 3) 2.

26 Olanrewaju T. Adedoyin, Ayodele O. Ojuawo, Omotayo O. Adesiyun, Femi Mark, Emmanuel Anigilaje, "Poisoning Due to Yam Flour Consumption in Five Families in Ilorin, Central Nigeria" (2008) 27 West Afr. Med. J. 41, 41-43.

27 Solomon I. Adeleke, "Food Poisoning Due to Yam Flour Consumption in Kano (Northwest) Nigeria" (2009) 8 Online J. Health Allied Scs. 10.

28 Susan Macmillan, "New Publication Warns of Rising Use of Antibiotics and Other Antimicrobial Drugs in Farm Animals", ILRI Clippings, News about livestock and development (2015) 11 <http://clippings.ilri.org/2015/03/30/ new-publication-warns-of-rising-use-of-antibiotics-and-other-antimicrobial-drugs-infarm-animals/> accessed 4 July 2016.

29 Morenike, A. Dipeolu, D.O. Alonge, "Residues of Streptomycin Antibiotic in Meat Sold for Human Consumption in Some States of SW Nigeria" (2002) 51 Núm Archivos de zootecnia 477, 477-480.

30 Ibid; See also Folasade Tolulope Ogunsola, "Apocalypse Now: A Call for a Coordinated National Response to Antibiotic Resistance" (Lecture delivered at the 7th Prof. Adesanya Ige Grillo Memorial Lecture at Obafemi Awolowo 
in fishing. They are also applied to stored products such as beans and grains or to vegetables such as carrots and cabbages to control insect infestation. ${ }^{31}$ However, as a result of poor cultivation and handling practices of some agricultural produce, the international market has had cause to reject Nigerian products due to pesticide residue. ${ }^{32}$

In addition, there have been allegations of food poisoning due to the chemicals used for food storage. ${ }^{33}$ For instance, in one incident in Rivers State, 112 people were reported to have been hospitalized after eating beans preserved with pesticides. ${ }^{34}$ Similarly, 120 students of a secondary school in Doma, Gombe State, allegedly became sick after eating food items contaminated by pesticides. ${ }^{35}$ There have also been allegations of carbide, ${ }^{36}$ balms and other insecticides used by fruit sellers in Nigeria to quicken the ripening of fruits. ${ }^{37}$

Studies on the personal and organizational hygiene of food handlers and their knowledge of good food safety practices have also revealed that much work persists in ensuring food safety in Nigeria. A study conducted in Owerri, Imo State, to establish the knowledge of food

University, Ile-Ife, Nigeria on 30th May, 2014) < http://chs.oauife.edu.ng/sites/ default/files/7th\%20Late\%20Prof.\%20T.A.I\%20Grillo\%2C\%202014.pdf> accessed 19 March 2018.

31 Jane Omojokun, "Regulation and Enforcement of Legislation on Food Safety in Nigeria" in Hussaini Makun (Ed.) Mycotoxin and Food Safety in Developing Countries (InTechOpen, 2013).

32 Federal Ministry of Health of Nigeria, "National Policy on Food Safety and Its Implementation Strategy", Abuja (2014) 12. < http://extwprlegs1.fao.org/ docs/pdf/nig151436.pdf > accessed 19 March 2018.

33 Ahmed D Agbo, "IITA Holds Seminar on Nonchemical Grain Storage Bags" Daily Trust (23 September, 2015) < https://www.dailytrust.com.ng/news/ agriculture/iita-holds-seminar-on-nonchemical-grain-storage-bags/ 112160.html> accessed 12 October, 2017,

34 J.A. Adegbola, Eunice I Bamishaiye, and Folorunsho Olayemi, "Merchants' Attitude towards the Use, and Ban of the Pesticide Gammalin in Dawanau International Grain Market, Kano, Nigeria" (2011) 2 Advances in Bioresearch 47, 47.

35 Ibid.

36 "We Only Use Carbide To Ripen Fruits - Association" Vanguard Newspaper (23 May, 2017). <http://www.vanguardngr.com/2017/05/use-carbide-ripenfruits-association/> accessed 16 October, 2017.

37 Jola Sotubo, "Fruit sellers are ripening mangoes, bananas with insecticide, balm" Pulse Nigeria (17 May 2017) < http://pulse.ng/health/health-warning-fruitsellers-are-ripening-mangoes-bananas-with-insecticide-balm-id6694314.html? ajax $=$ true $>$ accessed 16 October 2017. 
safety protocols by food handlers of different categories of restaurants, ${ }^{38}$ indicated a general lack of knowledge of the pathogens and food safety practices usually associated with foodborne disease outbreaks, especially in tropical environment. ${ }^{39}$ A great percentage of the respondents did not know that allowing a sick person to cook food exposes others to risk and could lead to foodborne illness. ${ }^{40}$ Another study of food vendors in Garki, Abuja, to assess their knowledge of food safety, contamination, poisoning and control measures revealed the lack of knowledge on safety and hygiene practices among food vendors (owners and staff). ${ }^{41}$

A study in the eastern part of Nigeria observed unsanitary conditions in the display of food. ${ }^{42}$ Butchers displayed their meats on tables without covering them. Meat sellers and customers constantly touched the meat with bare, unwashed hands and flies were a common sight. This practice has the potential to contribute to the microbial load of the meat. The hot and humid tropical environment of Nigeria is ideal for bacterial and fungal growth. ${ }^{43}$ Consequently, the high prevalence rate of leptospirosis, a zoonotic disease, from the blood samples of abattoir workers in Abuja, Benue, Plateau and Nassarawa States in another study, is a cause for worry, given the unsanitary manner in which meats are displayed. ${ }^{44} \mathrm{~A}$ recent, anonymous post on the social media indeed encouraged consumers not to buy meat that did not attract flies as that was indicative of another problem - the use of lethal substances in the preservation of the meat! In like manner, Nigerians woke up one morning to see newspaper reports and large photos of people exhuming truckloads of chickens that were considered unfit for human consumption and thus buried by the Customs Service.

Another study in the Federal Capital Territory found a high prevalence of intestinal parasites and bacteria in the stools of the food-

38 Class A -restaurants in major hotels; Class B-school cafeterias; Class C-regular/ fast food type; and Class D-"bukas" or "bukaterias" (food kiosks, roadside food sellers and itinerant food sellers or food hawkers).

39 Onyeneho and Hedberg (n 4) 3304.

40 Ibid.

41 Pepple (n 3).

42 John E. Ehiri, Marcel C. Azubuike, Collins N. Ubbaonu, Ebere C. Anyanwu, Michael O. Ogbonna, "Critical Control Points of Complementary Food Preparation and Handling in Eastern Nigeria" (2001) 75 Bull. World Health Organ. 423.

43 Ibid.

44 Ololade (n 24). 
handlers. It went on to conclude that food establishments should screen and treat staff with active illness, and regularly train them on good personal and workplace hygiene practices as food-handlers with poor personal hygiene working in food-serving establishments could be potential sources of infections of many intestinal helminths, protozoa, and entero-pathogenic bacteria. ${ }^{45}$

Unsafe water used for the cleaning and processing of food and poor food-production processes also contribute to a high risk environment. ${ }^{46}$ According to the WHO, one of the key principles of food safety is the use of safe water and raw materials for food preparation. A study in Are-Ekiti rural community in Ekiti State observed that despite increases in the incidence of Lassa fever and its increased awareness, some respondents still sun dry as a method of preserving their food. ${ }^{47}$ It concluded that the method of waste disposal and source of drinking water pose a threat to the health of the community residents, as there were indiscriminate wastes and bad food preserving methods. Refuse dumps constitute a habitat for vector and other nuisance organisms capable of transmitting or causing diseases such as typhoid, infantile diarrhoea and cholera in humans. ${ }^{48}$

\subsection{Consequences of an Ineffective Food Safety Regime}

Foodborne diseases pose more risk than vector-borne diseases. ${ }^{49}$ It is a public health problem that strains the healthcare system. The cost of illnesses associated with foodborne in the country was estimated at US\$3.6 billion per annum and the cost of beef-borne diarrhoea from

45 Chigozie O. Ifeadike O. C. Ironkwe, Prosper O. Adogu, Chinomnso C. Nnebue, Obiageli F. Emelumadu, Achunam Nwabueze, Chika F. Ubajaka, "Prevalence and Pattern of Bacteria and Intestinal Parasites among Food Handlers in the Federal Capital Territory of Nigeria" (2012) 53 Niger Med J 166.

46 World Health Organization, "WHO Estimates of the Global Burden of Foodborne Diseases; Foodborne Disease Burden Epidemiology Reference Group 20072015", (2015) 3. <http://apps.who.int/iris/bitstream/10665/199350/1/ 9789241565165_eng.pdf?ua $=1>$ accessed 12 October, 2017.

47 Ayodeji A. Fasoro, Charles O. Faeji, O. I. Oni, T. Oluwadare, "Assessment of Food Safety Practices in a Rural Community in Southwest Nigeria" (2016) 6 Food and Public Health 59.

48 Ibid.

49 Ifenkwe (n 16) 385. 
treatment and lost income was US\$854 million per year, as at $2011 .^{50}$ Ineffective food safety regime also has social implications as it affects consumer confidence. This, in turn, affects international trade as Nigerian products have been rejected at the international market. Foodborne diseases impede socioeconomic development by affecting the work force, productivity and economic growth. ${ }^{51}$

Effective food safety regime will not only protect the health of the consumers, ensure a healthy work force, improve productivity, strengthen the economy and increase food exports but it will also contribute significantly to the realization of Sustainable Development Goals (SDGs) 1, 2, 3, 4, 6, 8, 10, 11, 12, 15, 16 and $17 .{ }^{52}$

\section{REGULATORY FRAMEWORK ON FOOD SAFETY IN NIGERIA}

The food industry in Nigeria has been transformed to a regulated industry. ${ }^{53}$ Nigeria currently operates a multiple agency Food Safety Control System which is mostly sectorial. ${ }^{54}$ Enactment and implementation of food safety legislations are also fragmented between the three tiers of government: federal, state and local government area councils. At the federal level are the Federal Government Ministries of Health, Environment, Agriculture, Science and Technology, as well as Trade and Investment; with their Agencies - including the National Agency for Food Drug Administration and Control (NAFDAC); Standards Organization of Nigeria (SON); Consumer Protection Council;

50 ILRI, "Assessment of risks to human health associated with meat from different value chains in Nigeria: Using the example of the beef value chain. Nigeria Integrated Animal and Human Health Management Project" Draft Report, Nairobi, Kenya (ILRI 2011) < https://cgspace.cgiar.org/handle/10568/ $10251>$ accessed 16 October 2017.

51 Food Safety- Fact Sheet (n 1).

52 UNDP Nigeria, 2030 Agenda for Sustainable Development, Sustainable Development Goals, <www.ng.undp.org/content/nigeria/en/home/post2015/sdg-overview.html> accessed 20 June 2017.

53 "Communique of NIALS Roundtable on Food and Drug Law", 8th March, 2012, para $32<$ www.nials-nigeria.org/round_tables/ROUNDTABLE\%20ON\%20 FOOD\%20AND\%20DRUG\%20LAW.pdf.> accessed 12 May 2017.

54 Yetunde Oni, "National and International Food Safety Governance: Nigerian Perspective", Presentation by AG DG (NAFDAC) at the 1st Nigerian Food Safety \& Investment Forum, 7-8 February, 2017 < http://fsif.nqi-nigeria.org/docs/ d1/NAFDAC.pdf $>$ accessed 13 June 2017. 
Nigeria Customs Service; National Biotechnology Development Agency (NABDA); Nigerian Institute of Food Science and Technology (NIFST); National Agricultural Seeds Council; and the National Biosafety Management Agency. The Federal Ministry of Environment has a role to play in the control of environmental food contaminants, persistent organic pollutants, environmental pollution, waste disposal, etc. The Federal Ministry of Trade and Investment is the notification authority on World Trade Organization (WTO) Sanitary and Phytosanitary rules in Nigeria and, therefore, has a role to play in international trade in safe food. The Federal Ministry of Health, with its agency NAFDAC, has a significant role in the food safety regime.

The states have the State Ministries of Health and Agriculture as well Local Government Departments of Health and Agriculture at the local government level. The Local Government Areas are usually responsible for street-vended foods, bukaterias, catering establishments, local abattoirs and traditional markets. ${ }^{55}$ The role of the private sector in effectively regulating and ensuring food safety must also be recognized. International Development Partners and NonGovernmental Organizations (NGOs) play a key role in training and capacity building. Universities and Research Institutes help shed light on the issues by conducting researches and producing policy briefs on food safety and providing scientific basis for policy development and programme design. Professional bodies and associations as well consumer associations equally engage in industry guidelines, workshops as well as in self-regulatory regimes.

Several legislative provisions have been enacted in response to food safety challenges. ${ }^{56}$ The NAFDAC Act ${ }^{57}$ is an important legislation

55 Omojokin (n 31) 257-58.

56 Some of these legislative provisions include Laws of the Federation of Nigeria, Public Health Ordinance, Cap 165 of 1958; The Standards Organization of Nigeria Decree No 56 of 1971; The Food and Drugs Decree No 35 of 1974; The Animal Disease Control Decree No 10 of 1988; The Marketing of Breast Milk Substitute Decree No 41 of 1990; Food and Drugs Act, (Cap 150) of 1990, Sea Fisheries Act No. 71 of 1992; National Agricultural Seeds Act 1992; The Public Health Laws (1917) now known as Public Health Ordinance Cap 164 of 1958; The Food and Drugs Decree, No. 35 of 1974; The Standards Organization of Nigeria Decree, No. 56 of 1971; The Animal Disease Control Decree, No. 10 of 1988; The Marketing of Breast Milk substitute Decree, No. 41 of 1990. The National Agency for Food and Drugs Administration and Control (NAFDAC) Decree No. 15 of 1993, Hygienic Code of Practice for handlers by NAFDAC; Regulation C/REG.4/05/2008 on Harmonization of the Rules Governing 
on food safety. By the provisions of Sections 5 and 30 of the NAFDAC Act, the Agency came up with food-related regulations on Food Irradiation, Additives, Food Marketing of Infant and Young Children, Fortification Regulations, Cocoa Products Regulations, Milk and Dairy Products regulations, Pre-packaged Food (Labelling) Regulations, Pesticide Registration Regulations, etc.

The Food and Drugs Act ${ }^{58}$ (FDA), another important legislation, prohibits under Section (1a) the sale, importation, manufacture or storage of any article of food, which has in it or upon it any poisonous or harmful substance not being a food additive or contaminant of a type and within the level permitted by regulations made under this Act. This section needs to be amended as the allowance of "poisonous or harmful substance that is a food additive or contaminant within the level permitted by the regulations" made under the Act needs more qualification. With constant innovation and research in science, substances not hitherto identified as very harmful and dangerous are suddenly discovered to be so. For example, the Red dye \#3 (also Red \#40 - a more current dye) (E124) was found to be harmful and was banned in 1990 after eight years of debate on its use in the food industry. The dye has been proven to cause thyroid cancer and chromosomal damage in laboratory animals and may also interfere with brain-nerve transmission. ${ }^{59}$

Therefore, permitted levels are constantly changing, and a more holistic and proactive approach to prevention of harmful food under this section should be envisaged. The decision of the Lagos State High

Quality Control, Certification and Marketing of Plant Seeds and Seedlings in the ECOWAS Region (ECOWAS Regulation); Regulation on the harmonization of rules pertaining to the safety of foods of animal and plant origin within the ECOWAS region, 2011; Laws of the Federation of Nigeria, The National Biosafety Management Agency Act, 2015, Laws of the Federation of Nigeria, Agriculture (Control of Importation) Act. CAP. A 13 L.F.N. 2004, Laws of the Federation of Nigeria, Agricultural and Rural Management Training Institute CAP. A 10 L.F.N. 2004, Laws of the Federation of Nigeria, Food, drugs and related products (registration, etc.) Act cap. F32 L.F.N. 2004.

57 Law of the Federation of Nigeria, CAP N1, L.F.N, 2004.

581 Law of the Federation of Nigeria, Food and Drugs Act 1999, CAP. F32 L.F.N. 2004. < http://lawsofnigeria.placng.org/laws/F32.pdf> accessed 8 February 2018.

59 Joseph Mercola, “Top 10 Food Additives to Avoid”, Food Matters (23 November 2010) www.foodmatters.com/article/top-10-food-additives-to-avoid accessed 30 April 2018. 
Court in the case Fijabi Adebo Holdings Limited \& Anor v. Nigerian Bottling Company Plc \& Anor, that Fanta and Sprite contain excessive levels of benzoic acid and sunset additives which make them unsafe for human consumption, is commendable and reveals the use of excessive and unpermitted levels in the Nigerian food industry, even by the formal sector. $^{60}$

In the same vein, Section 6 of the FDA provides that "no person shall under unsanitary conditions manufacture, prepare, preserve, package or store for the purpose of selling, any food..." while Section 17 (1) provides the punishment for contravening the rules as "not less than fifty thousand naira or imprisonment for a term not exceeding two years or to both such fine and imprisonment." While this provision is commendable and wide enough to accommodate most cases of unsanitary conditions, the word "unsanitary" is not defined in the Act. Insanitary, a synonym of unsanitary, was however defined in Section 21 to mean "such conditions or circumstances as might contaminate any food, drug or cosmetic with dirt or filth or render it injurious to health." This leaves prosecution under that section difficult as the interpretation of unsanitary will be relative to the level of hygiene of the interpreter.

Given this discretion, it would have been better to empower the Minister explicitly, under Section 16 of the Act, to make regulations on sanitary requirements and environment for food handling and preparation. Such a regulation would offer a guide as to what will constitute an unsanitary condition. For example, it could stipulate the minimum distance between a food preparation point and toilet facilities, refuse dumps or chemical stores. It could also stipulate the minimum quantity (litres) of water that should be found around any food preparation point. Article 14 (3) of the European Union Regulation on Food safety, ${ }^{61}$ is an example of such explicit description as it described

60 George Etomi \& Partners, "Fijabi Adebo Holdings Limited \& Dr. Emmanuel Fijabi Adebo Vs. Nigeria Bottling Company Plc \& National Agency for Food and Drug Administration and Control (NAFDAC)" LD/13/2008 Judgement, delivered on 15 February 2017, Lexology (Nigeria, 18 May 2017). <https:// www.lexology.com/library/detail.aspx?g $=22171143-1 \mathrm{f} 49-49 \mathrm{fe}-8 \mathrm{a} 07-$ 71a3753ba080 > accessed 16 June 2018; Admin, "Food safety in Nigeria: The law and preventing the next Fanta/Sprite food scandal" The Daily Times (Lagos, 12 February, $2018<$ https://dailytimes.ng/food-safety-nigeria-law-preventingnext-fanta-sprite-food-scandal/> accessed 30 April 2018.

61 European Parliament and of the Council Regulation (EC) 178/2002 on general principles and requirements of food law, establishing the European Food Safety 
certain circumstances that will assist in determining where food will be ascertained as unsafe.

It is correct that the mere stipulation of these provisions in the Act or in a regulation will not automatically translate to observing more sanitary condition, but they are good guides and indicators on sanitary conditions. It remains unfortunate that enforcement and prosecutions under this Act are seldom carried out. ${ }^{62}$ This could be attributed to negligence and neglect by the regulating authorities. The question of corruption will also not be ruled out, as regulators have been accused of collecting bribes and turning a blind eye. ${ }^{63}$

In addition, there are no provisions under the NAFDAC Act and the FDA or any regulations by NAFDAC on traceability requirements for food business operators and food handlers. It is necessary, as provided under Article 18 of the European Union Regulation on food safety, ${ }^{64}$ that food business owners and handlers should be able to identify any person from whom they have been supplied any food substance and to whom they have also sold to. They should have systems and procedures that allow this information to be made available to competent authorities on demand. It is important to note here that traceability does not make food safe but acts as a risk control tool to be used in curbing a food safety problem. ${ }^{65}$

There are also state laws on sanitation in most states in Nigeria, especially as regards cleaning abattoirs and the general environment. These laws come in different forms, such as State Environmental Protection Laws, State Environmental Sanitation Authority Laws, State Rural Water \& Sanitation Agency Laws, State Waste Management Laws, Environmental \& Waste Management Laws, State Rural Water Supply

Authority and laying down procedures in matters of food safety [2002]L31/ $1<$ www.reachteam.eu/english/REACH-ME/engine/sources/regulations/ launch-178-2002-EC.html> accessed 29 April 2018.

62 <www.vanguardngr.com/2015/04/food-safety-how-safe-is-food-in-nigeria/> accessed 30 April 2018.

63 Admin, "Food Safety: Politicking Policies" The National Daily, (31 March 2016) <https://nationaldailyng.com/11787-2/> accessed 1 May 2018.

64 Regulation (EC) 178/2002 (n 61).

65 EC Guidance, "EC General Food Law Regulation 178/2002: Guidance Notes on the Food Safety (Northern Ireland) Order 1991 (Amendment) Regulations (Northern Ireland) 2004 and the General Food Regulations (Northern Ireland) 2004 <www.food.gov.uk/sites/default/files/media/document/fsogfrni 2004.pdf $>$ accessed 29 April 2018. 
\& Sanitation Agency Laws, State Environmental Pollution Control Laws, etc.

Notwithstanding these several legislations that concern food safety ${ }^{66}$ there appeared to be little regulation on food safety. It became necessary to revise and harmonize existing legislations. This gave rise to the National Policy on Food Hygiene and Safety in 2000. The policy sought to stimulate and promote all government regulations concerned with food production, storage and food handling, food manufacturing/ processing/preservation, food trade and distribution as well as food preparation. ${ }^{67}$ Again, in 2010, the Government of Nigeria also launched the National Policy of Food Hygiene and Safety as an integral part of the National Health Policy. The overall goal of this policy was the attainment of high standard of food hygiene and safety practices, which will promote health, control foodborne diseases, minimize and finally eliminate the risk of diseases related to poor food hygiene and safety. ${ }^{68}$

However, as food safety activities remained fragmented and compounded by overlap of functions of the government regulatory bodies with different roles along the farm-to-table continuum, the National Policy on Food Safety was adopted in 2014. It aims to integrate and harmonize all existing laws, standards and codes that regulate food safety practices in Nigeria; redefine and coordinate existing food control infrastructure at various levels of government, and eliminate areas of overlap and conflict. Implementation of the National Policy on Food Safety (NPFS) is envisaged to minimize the risk of an outbreak of diseases arising from poor safety practices and reduce the prevalence of foodborne and related diseases. ${ }^{69}$

It is important to note that the process of developing food safety policies involves three interlocking stages, comprising several steps: policy development, policy implementation, and policy performance and implementation monitoring. ${ }^{70}$ Nigeria has successfully developed its food safety policy. The development of the policy entailed stakeholder

66 Seen 56.

67 WHO AFRO, Food Safety, Nutrition and Food Law Guidelines (2002) 5. < http:/ /www.afro.who.int/sites/default/files/2017-06/Food\%20Safety\%20and\%20 Nutrition\%20Food\%20Law\%20Guidelines.pdf> accessed 13 October 2017.

68 JT Nyor, "The Role of Regulatory Agencies in Food Quality Control in Nigeria" (2014) 1 SCSR Journal of Agribusiness 1, 1-2.

69 Omojokun (n 31) 255.

70 WHO AFRO (n 67) 7. 
identification and participation, engaging in situation analysis, drafting of the national policy with inputs from stakeholders, circulation and finalization of the policy document, formal endorsement and approval of the document, and dissemination of the policy document widely. ${ }^{71}$

For the implementation of the Food Safety Policy, implementation strategies should be defined and developed. This will entail defining what priority interventions are needed, at what stage and how soon, who is responsible, what are the budgetary requirements are needed. It will also include timeframe with clearly defined milestones and reporting mechanisms so that progress can be monitored. To support timely and effective implementation of the different components of the plan, capacity building and training should be considered. ${ }^{72}$ Nigeria is still at this implementation stage. Once the policy has been put in place and implemented, its effectiveness and success should be evaluated. Monitoring and evaluation procedures need to be incorporated at every stage of implementation. Any shortcomings should be noted and suggestions put forward as to how strategies would need modification in the future. ${ }^{73}$

\section{ISSUES REQUIRING REFORM}

The definition of "food" offered under the food laws limits the regime of food safety. The provisions clearly exclude raw food especially live animals and poultry (without qualification), an important component of food safety regime. Under Section 21 paragraph 5a of the Food and Drugs Act, ${ }^{74}$ "food" includes:

any article manufactured, processed, packaged, sold or advertised for use as food or drink for human consumption, chewing gum and any ingredient which may be mixed with food for any purpose whatsoever and excludes (a) live animals, birds or fish.

This is the same definition under Section 13 paragraph 6a of Food, Drugs and Related Products (Registration, etc.) Act. ${ }^{75}$ A slightly

71 Ibid 7-11.

72 Ibid 12.

73 Ibid 13.

74 Laws of the Federation of Nigeria, Food and Drugs Act, Cap F32 L.F.N 2004.

75 Ibid. 
extended version is under Section 22 ( $f$ ) of the National Agency for Food and Drug Administration and Control Act to include drinking water. The section provides thus:

"food" means any article manufactured, sold or advertised for use as food or drink and includes drinking water, chewing gum, and such other ingredients as may be mixed with food for any purpose whatsoever including supplements processed for addition to animal and poultry feeds.

Therefore, it will be necessary to extend the boundary of definition to adequately determine whether for example raw cassava can be described as food or if only its processed forms as garri, fufu or starch will qualify as food. This is important so as to bring the regime of food safety to farm production activities and the use of agrichemicals thereof - the beginning part of the food chain system and the inclusion of the informal food sector.

The European Union Regulation on food safety ${ }^{76}$ is a good example of a provision that adequately defines food to accommodate a whole range of activities in the food chain system. It provides under Article 2 as follows:

Food (or Foodstuff) - any substance or product, whether processed, partially processed or unprocessed, intended to be, or reasonably expected to be ingested by humans. "Food" includes drink, chewing gum and any substance, including water, intentionally incorporated into the food during its manufacture, preparation or treatment.

It includes water after the point of compliance as defined in Article 6 of Directive 98/83/EC and without prejudice to the requirements of Directives 80/778/EEC and 98/83/EC. It goes on to qualify the exclusion list as follows:

"Food" shall not include: (a) feed; (b) live animals unless they are prepared for placing on the market for human consumption; (c) plants prior to harvesting; (d) medicinal products within the meaning of Council Directives 65/65/EEC and 92/73/EEC;...

This provides clarification for a number of situations where more precision is needed at the interface with other legislation. As an

76 Regulation (EC) 178/2002 (n 61). 
example, it was considered necessary to clarify the circumstances under which "water" is considered as a food item and when it is covered by water supply requirements. The sale of bottled water is considered as a sale of food, but when the water is in pipes, it is subject to a different legislation. ${ }^{77}$ It clarified that plants are not food prior to harvesting and live animals are not food unless they are prepared for placing on the market for human consumption. The Nigerian food laws should be brought in line with this, if it must effectively tackle the regulation of food processes from the farm to fork.

On product labelling, compliance with the legislation on labelling of food may be high for durable commodities, but low for perishable food items. In addition, misbranding, that is, having false and misleading statements on food labels, and adulteration which are both criminal offences under Section 5a of the Food and Drug Act, subsist. ${ }^{78}$ Basic information required on food labels, according to the Oxford Handbook of Nutrition and Dietetics (OHND), include product name, ingredient list and quantity, qualitative ingredient declaration, allergenic ingredients and shelf life. Others are storage instructions, name and address of manufacturers, packers or sellers, country of origin, weight or volume and instructions for use. ${ }^{79}$ Accounts abound in Nigeria of cases of false and misleading information for some adulterated and sub-standard products. For example, sugar syrups are misrepresented as natural honey in the ingredient list. ${ }^{80}$ It is within the personal knowledge of this author that some coconut oil, natural honey, spices, palm oil, flour and some other food items are adulterated and misbranded. Concerted effort is needed to enforce the labelling requirements. This also applies to tampering with expiry dates, which is prohibited under the same section. It is also within the personal experience of the author to have bought biscuits, cereals, milk and

77 WHO AFRO (n 67), 66.

78 "CPC, NAFDAC Collaborate against Adulteration of Food and Drugs", PM News (16 March 2018) <www.pmnewsnigeria.com/2018/02/25/cpc-nafdaccollaborate-adulteration-food-drugs/ > accessed 16 June 2018; Ayo Oyoze Baje, "Nigeria: The Evil of Adulterated Drinks", The Guardian (26 April 2018) <http://allafrica.com/stories/201804260723.html> accessed 1 May 2018.

79 Ifenkwe (n 16) 388.

80 Ridwan A. Lawal, Adekunle Lawal and J.B. Adekalu, "Physico-Chemical Studies on Adulteration of Honey in Nigeria" (2009) 12 Pakistan Journal of Biological Sciences 1080 . 
beverages that have their expiry dates tampered with. ${ }^{81}$ Figures like six are changed to eight, moving the expiry dates from, for example, 2016 to 2018.

On the other hand, the legislations must take into cognisance the need to provide different levels of labelling requirements for durable and perishable items. For instance, there should be different labelling requirements for powdered milk and home-made cake, or Coca-Cola's Fanta and the traditional zobo. In all of this, the culture of Nigerians and the level of poverty or unemployment should be considered in placing these requirements, in order to regulate the informal food sector, without an attendant strain on those trying to make a living for themselves. For example, insisting that a poor vegetable retailer packages and labels her products with expiry dates, as done in some climes, will not be appropriate for the Nigerian informal sector because of the level of unemployment and education.

The need for a proactive legal and judicial engagement cannot be overemphasized in the bid to ensure an effective food safety regime. Nigerian lawyers can take a clue from Mr Bill Marler, a United States food safety lawyer and a food policy change agent in the U.S, whose law firm, Marler Clark, has represented thousands of individuals in claims against food companies whose contaminated products have caused life-altering injury and even death. ${ }^{82} \mathrm{He}$ has filed lawsuits against such companies as Chili's, Chi-Chi's, Cargill, ConAgra, Dole, Excel, Golden Corral, KFC, McDonald's, Odwalla, Peanut Corporation of America, Sheetz, Sizzler, Supervalu, Taco Bell and Wendy's, securing over US $\$ 600,000,000$ for victims of foodborne illnesses. ${ }^{83}$ Some of his cases contributed to successfully moving forward the Food Safety Modernization Act in 2010. ${ }^{84}$

On food production activities, quality systems such as good agricultural practices (GAP) should be recommended for farms, to provide a basis for the development of best practices in the production

81 The author has tried to interrogate some of the sellers and their response is that the products still look good and have not perished.

82 Marler Clark, "Food Safety Attorney Bill Marler Recognized as One of The Best Lawyers in America" Food Poison Journal (18 August 2017) $<$ www.foodpoisonjournal.com/food-poisoning-information/food-safetyattorney-bill-marler-recognized-as-one-of-the-best-lawyers-in-america > accessed 20 October 2017.

83 Ibid.

84 Ibid. 
of agricultural products (fruits, vegetables, potatoes, salads, etc.). GAPs, such as early harvesting; proper drying, sanitation, proper storage and insect management, among other things, are some of the strategies employed to prevent fungal infections. ${ }^{85}$ Farmers and traders should be exposed to non-chemical storage methods and Integrated Pest Management options. ${ }^{86}$ For instance, a mixture of the neem and moringa seed oils at $1.5 \mathrm{~mL} / 200 \mathrm{~g}$ have been said to be effectively used to store cowpea for several months. ${ }^{87}$

At the consumer's level, foodborne illnesses can be reduced by proper cooking of meat, poultry and eggs to temperatures that will kill bacteria. ${ }^{88}$ This is notwithstanding the culture and preferences of some people to consume half-cooked meat and eggs. ${ }^{89}$ It is a safer way to stay healthy. Additionally, refrigerating leftovers promptly and storing foods at recommended temperatures; avoiding cross-contamination of cooked and raw foods; washing of utensils and surfaces before and after use with hot, soapy water; and frequently washing hands and/or using gloves when preparing food should all be recommended and enforced. ${ }^{90}$ Conversely, those that cannot afford refrigerator, constant electricity, soap or gloves can practice other effective food storage and personal hygiene methods like washing hand with ash, etc. This awareness should be incorporated in a nationwide public campaign on food safety practices, in line with the National Food Policy.

There is also a need to debunk the assertion that "dirty (germ/ disease) no dey kill African man" popularly chanted by the consuming

85 Mirriam E Nyenje and Roland N Ndip "The Challenges of Foodborne Pathogens and Antimicrobial Chemotherapy: A Global Perspective" (2013) 7 African Journal of Microbiology Research 1158, 1167-68.

86 J.A. Adegbola, Eunice I. Bamishaiye and Folorunsho Olayemi, "Merchants' Attitude towards the Use, and Ban of the Pesticide Gammalin in Dawanau International Grain Market, Kano, Nigeria" (2011) 2 Advances in Bioresearch 47, 47.

87 Joana O. Ilesanmi and Daniel T. Gungula, "Preservation of Cowpea (Vigna unguiculata (L.) Walp) Grains against Cowpea Bruchids (Callosobruchus maculatus) Using Neem and Moringa Seed Oils" [2010) International Journal of Agronomy 1.

88 Olumide A. Odeyemi, "Public Health Implications of Microbial Food Safety and Foodborne Diseases in Developing Countries" (2016) 60 Food \& Nutrition Research. < https://www.ncbi.nlm.nih.gov/pmc/articles/PMC5103665/> accessed 16 June 2018.

89 The author has encountered arguments, during this research that some people or cultures prefer to eat half cooked meat.

90 Nyenje and Ndip (n 85) 1168. 
public. ${ }^{91}$ Studies and data that show the frequency of foodborne illness should be widely disseminated to inform the consuming public of the dangers. The argument that a hungry or poor man may not be bothered about the quality and safety of the food being consumed ${ }^{92}$ can be debunked by the statement that, "if it is not safe, it is not food. ${ }^{93 "}$ "It would be better not to eat than to eat and spend a lot more money treating oneself.

The recent creation of the Food Safety and Applied Nutrition Directorate at the NAFDAC is commendable. Its role is to take all steps to ensure that food manufactured, imported, exported, distributed, sold and marketed in Nigeria meets the highest standard of food safety reasonably available. ${ }^{94}$ The problem has, however, always been that they concentrate on the formal sector and neglect regulating the informal groups. ${ }^{95}$ Though the law does not effectively cover the informal sector, ${ }^{96}$ it does not limit their authority to regulate it either. Therefore, it would be necessary to have a comprehensive task force, with officers drawn from the relevant agencies, to work with this directorate, to be created in each Local Government Area to monitor compliance with regulations at the farms, slaughterhouses, processing plants and food retail outlets. ${ }^{97}$ While at the moment, food handlers and inspection units exist in most local governments, they mostly engage in levy

91 Mcadioh, "You Will Think Twice About Eating Suya Meat After Seeing This", Naija News ,(7 April 2018) <www.naijaloaded.com.ng/news/you-will-thinktwice-about-eating-suya-meat-after-seeing-this-photos $>$ accessed 30 April 2018.

92 As raised by some people encountered by the author during this research.

93 Joseph James Whitworth , "FERG: Global Estimates Must Drive Country Action", Food Navigator (22 December 2015) <www.foodnavigator.com/Article/2015/ $12 / 22$ /Country-studies-needed-to-guide-action-on-foodborne-diseases $>$ accessed 1 May 2018.

94 NAFDAC, "Food Safety and Applied Nutrition (FSAN)", <www.nafdac.gov.ng/ index.php/about-nafdac/directorates/food-safety-applied-nutrition $>$ accessed 1 May 2018.

95 Flora-Glad Ekezie, "Regulation and Enforcement of Food safety in Nigeria" (2015) Slides 7 and 8, <www.slideshare.net/apexflora/regulation-andenforcement-of-food-safety-in-nigeria >accessed 1 May 2018.

96 For example, the definition of food needs to be expanded to accommodate certain food stuffs sold by the informal sector.

97 Mojisola Ojebode, "Nigerian Regulatory Agencies and Food Poisoning" Financial Nigeria (3 May 2017) <www.financialnigeria.com/nigerian-regulatoryagencies-and-food-poisoning-blog-247.html> accessed 17 October 2017. 
collections and seldom carry out any inspection. ${ }^{98}$ There is need for sensitization amongst them and capacity building to strengthen their capacity.

\section{PRACTICAL CHALLENGES OF REGULATING FOOD IN NIGERIA}

Adequately regulating the food regime in Nigeria will come with challenges. The issue of food safety and foodborne toxicants in Nigeria is exacerbated by public ignorance on the subject, uncoordinated approach to food control, lack of technical expertise, poorly equipped laboratories, poor enforcement of legislation and regulatory limits. ${ }^{99}$ Others include lack of understanding of food safety and quality standards as outlined in international agreements; inadequate infrastructure and resources to support scientific risk management, inefficient food supply chain and poor traceability. ${ }^{100}$ Lack of awareness of the socioeconomic importance of food safety due to paucity of data and information on the incidence of foodborne disease outbreaks is another major challenge. ${ }^{101}$

A major obstacle to food safety in Nigeria is the poor refuse disposal and lack of toilet facilities for the customers. ${ }^{102}$ Food is often prepared in unsanitary conditions because of poor water supply and poor drainage systems. ${ }^{103}$ These predispose conditions favourable to contamination. Another mundane challenge is the superstitious belief in many parts of Nigeria, where food poisoning is usually associated with evil spirit, malice or curses. ${ }^{104}$

98 Charles Adingupu, "Mile 12 Market: Traders, Drivers Groan Under Multiple Levies" The Vanguard (11 August 2012) <www.vanguardngr.com/2012/08/ mile-12-market-traders-drivers-groan-under-multiple-levies $>$ accessed 1 May 2018.

99 Omojokun (n 31) 251-52.

100 Oni (n 54).

101 Onyeneho and Hedberg (n 4) 3298.

102 Fasoro and others (n 47); Ehiri and others (n 42).

103 Ehiri and others (n 42).

104 A. Oyemade, Folashade O. Omokhodion, J F Olawuyi, M.K.C. Sridhar, I. O. Olaseha "Environmental and Personal Hygiene Practices: Risk Factors for Diarrhoea among Children of Nigerian Market Women" (1998) 6 IOJ Diarrhoeal Dis Res, 241. 
Socio-security and climatic conditions like war, drought and political insecurity can result in a great challenge for effective regulation. ${ }^{105}$ Climate change, where temperature changes modify food safety risks associated with food production, storage and distribution, has impact on food safety. ${ }^{106}$ The growing population rate also increases the burden on food security and a relaxed attitude by the consuming public and the regulators alike.

Most of these challenges can be overcome with an intensive public campaign to educate the food handlers and the consuming public as well as a concerted effort to synergise amongst the relevant agencies, as envisaged in the national policy on Food safety. For example, the strategic partnership between NAFDAC and the National Bio-safety Management Agency aimed at ensuring food safety in the country is commendable, as both agencies articulated a Memorandum of Understanding (MoU) in 2016 to facilitate and strengthen their collaboration. ${ }^{107}$

\section{CONCLUSION}

This article has interrogated the agitation for effective regulations that ensure food safety in Nigeria. It examined the various cases of foodborne outbreaks in Nigeria and evaluated the role and ambit of food safety regulation by the regulatory agencies. It argued that the present regulatory framework does not permit adequate control of the informal sector that serves the majority of the Nigerian consumers. This is because of the narrow provisions in the food laws, overlap of regulatory functions, neglect, and corruption. If Nigeria must be proactive in food safety matters, then the issues identified to require reform must be addressed. Our definition of food should be expanded and clarified, to accommodate adequate regulation of most food substances. It should be expanded to include any substance or product, whether processed, partially processed or unprocessed, intended to be, or reasonably expected to be ingested by humans. It should clarify whether plants are considered food after harvesting and if live animals are food where they are prepared for placing on the market for human consumption.

105 Omojokun (n 31) 251-52.

106 Food Safety - Fact Sheet (n 1).

107 Ayo Oyoze Baje, "FSAN and food safety" Business Day Online (18 June 2017) <www.businessdayonline.com/fsan-food-safety/> accessed 20 October 2017. 
While prosecution is seldom done, such narrow definitions as present in our laws may prevent a conviction. Therefore, the Food Safety Bill at the National Assembly should be expediently passed, ${ }^{108}$ taken into consideration these observations and recommendations made. This is to ensure that our food is produced, processed, preserved, promoted, publicized and prepared in a safe and hygienic manner.

108 Ojoma Akor and Olayemi John-Mensah, "Nigeria's Food Safety Laws Outdated - UNIDO", Daily Trust (24 January 2017) < www.dailytrust.com.ng/news/ general/nigeria-s-food-safety-laws-outdated-unido/182240.html > accessed 1 May 2017. 